\title{
Surfaces
}

\section{More Enlightened Than Thou: The Dangers of Idealizing Knowledge in the Disciplines}

\section{Wes Cecil}

Volume 5, 1995

\section{CULTURE AND INSTITUTIONS}

URI : https://id.erudit.org/iderudit/1064988ar

DOI : https://doi.org/10.7202/1064988ar

Aller au sommaire du numéro

Éditeur(s)

Les Presses de l’Université de Montréal

ISSN

1188-2492 (imprimé)

1200-5320 (numérique)

Découvrir la revue

Citer cet article

Cecil, W. (1995). More Enlightened Than Thou: The Dangers of Idealizing Knowledge in the Disciplines. Surfaces, 5. https://doi.org/10.7202/1064988ar
Résumé de l'article

Dans le contexte de la crise d'identité actuelle de l'université, cet essai analyse les implications de la création d'une université " post-disciplinaire ». Un examen critique des textes de Frank Lentricchia, James Sosnoski et Judith Butler révèle les enjeux institutionnels et épistémologiques d'une vision postdisciplinaire de la structure universitaire. Sur cette toile de fond, cet essai termine en démontrant comment le savoir idéalisé, en tant que séparé du conflit, aboutit à une sous-estimation systématique de l'importance des disciplines pour les structures philosophiques, physiques et administratives qui soutiennent l'université ainsi que les disciplines elles-mêmes. 


\section{More Enlightened Than Thou : The Dangers of Idealizing Knowledge in the Disciplines}

Wes Cecil

WCECIL@Indiana.Edu

Surfaces Vol.V.103 (v.1.0A - 06/12/1995)

Copyright for texts published in SURFACES remains the property of authors. However, any further publication should be accompanied by an acknowledgement of SURFACES as the place of initial publication.

ISSN: $1188-2492$

\section{ABSTRACT}

In the context of the university's current identity crisis, this essay analyzes the implications of creating a "post-disciplinary" university. A critical discussion of texts by Frank Lentricchia, James Sosnoski, and Judith Butler reveals the institutional and epistemological stakes of postdisciplinary views of the University structure. Against this backdrop, the essay concludes by showing how idealizing knowledge as separable from all strife leads to a systematic underestimation of the disciplines' importance for the philosophical, physical, and administrative structures that undergird the university and the disciplines themselves.

\section{RÉSUMÉ}

Dans le contexte de la crise d'identité actuelle de l'université, cet essai analyse les implications de la création d'une université "post-disciplinaire". Un examen critique des textes de Frank Lentricchia, James Sosnoski et Judith Butler révèle les enjeux institutionnels et épistémologiques d'une vision postdisciplinaire de la structure universitaire. Sur cette toile de fond, cet essai termine en démontrant comment le savoir idéalisé, en tant que séparé du conflit, aboutit à une sous-estimation systématique de l'importance des disciplines pour les structures philosophiques, physiques et administratives qui soutiennent l'université ainsi que les disciplines ellesmêmes. 


\section{Revolution is the opiate of the intellectuals}

As Samuel Weber notes in Institution and Interpretation there is a widespread identity crisis affecting myriad academic disciplines that indicates an ongoing attempt to reconceptualize "the academic division of labor itself" (Weber, $\mathrm{x}$ ). One example of the attempt to re-think the strict division of academic work into various self-sustaining disciplines is the call for a "post-disciplinary" University. For the purposes of this essay, I will focus on the calls for a post-disciplinary academy by Frank Lentricchia, James Sosnoski, and Judith Butler. All three are intent on reforming the University by eliminating, surpassing or variously challenging the division of fields of knowledge into disciplines. All three identify the disciplines as the locus of essentialist assumptions about knowledge which departmentalize academic work in the name of autonomy 1 and professionalism. What is missed in the arguments promoted by Lentricchia, Sosnoski, and Butler is the degree to which the disciplines are foundational to the idea of the University. In calling for a "post-disciplinary University" all three fail to adequately read the history of the University and mistakenly assume that the disciplines are separable from the University, when the disciplines are perhaps the definitive mark of the University. Each re-enacts the enlightenment idealization of knowledge by replaying the mind/body split. All three are able, therefore, to completely ignore the physical manifestations of the disciplinary structure, the University in all of its institutional manifestations, and argue that a reformation of the disciplines (mind) is sufficient to make the University (body) healthy again. This misreading of history is perpetuated in the call for a surpassing and/or negating of the disciplines represented by the use of the prefix "post" which, while intent on questioning the bounds of disciplines like history, ends up suggesting the teleological view of history that underwrites the legitimacy of history as a discipline in the first place. Finally, the failure to recognize the constitutive nature of the disciplines for the structure of the University prevents them from taking into account either the organizational posts of the university, the faculty chairs, administration and staff, or the physical posts which demarcate the university with a series of gates. Having correctly identified the disciplines as a key issue of the University, Lentricchia, Sosnoski, and Butler seriously underestimate the influence that the disciplinary ideal has on the University. In limiting their calls for reform to "the disciplines" (History, English, Philosophy), rather than raising the much broader question of disciplinarity, they are able to deploy the notion of the post-disciplinary as a panacea that would seem to address some nagging intellectual issues, specifically the essentialization of knowledge, without having to exercise themselves unduly about the greater ramifications of the disciplinary structure that underlies the University.

Lentricchia, unlike Sosnoski and Butler, does not champion the postdisciplinary directly. Rather, he has a champion, Kenneth Burke, $\underline{2}$ and contents himself with retelling Burke's anti-disciplinary exploits. Burke, for Lentricchia, highlights the limits in the disciplines, most specifically in this case History: 
For more than fifty years, Burke . . . has been telling us that the conventional division of the humanities, with literature, philosophy, history, linguistics, and social theory . . . is all, at best a lie of administrative convenience, and at worst, a re-enforcement in our institutions of higher education of bourgeois-capitalist hegemony. (Lentricchia, 119-20)

Lentricchia characterizes Burke's career as a series of strategic engagements with the question of history by a "resistance to system [the system of the disciplines] and in particular by a resistance to the essentializing consequences of systematic thought" (121). $\underline{3}$ Burke's approach to analyzing history is problematic only when historians try to bring him into the disciplinary setting of the academy. So where Burke generally ignores the disciplines, Lentricchia wants to import Burke into the academy as a model for University intellectuals who want to be postdisciplinary.Lentricchia argues that Burke "with his rare integration of the resources of technical, formalist criticism and social and political investigation ... set[s] standards for the ideological role of intellectuals that contemporary theory would do well to measure itself by" (Lentricchia, 147). Lentricchia is explicitly challenging us to go "beyond" the limits of disciplinary studies and to integrate, like Burke, divergent fields in our work. Burke is not the only model for post-disciplinarity, however, as announced by the title to the essay, "Reading History with Kenneth Burke"; to the extent that Burke has accomplished the resistance to disciplines outside the academy, Lentricchia will replay it "with Burke" inside the academy and, hence, casts himself as already starting to post the disciplines, by performing what he calls elsewhere $\underline{4}$ "radical" acts of reading.

Sosnoski, like Lentricchia, finds the "ideals and goals of disciplinarity . . . no longer defensible intellectually or politically" (Sosnoski, 7). Elaborating this argument in "Literary Study in a Post-Modern Era: Rereading its History," Sosnoski finds the humanities suffering from the "alienating disciplinary practices of examining, hiring, promoting, granting, and so on" which finally "marginalize and tokenize" the intellectual (Sosnoski, 8). Casting himself as a "post-modern" and invoking a "Lyotardian" sense of history, he wants to critique the disciplines and move to a "post-disciplinary" inquiry in which the "political character of literary studies surfaces" (Sosnoski, 28). By challenging the authorities which constitute and underwrite the disciplines, we could, it would seem, move beyond academic structures of essentialist representation to a

post-modern inquiry that would not be totalizing; it would not ascribe to a disciplinary epistemology; it would concern subjects rather than objects; would not have as its generative principle a logic of consistency. (Sosnoski, 26)

The point of this is not, as Sosnoski reassures us, to challenge the institution per se, but to achieve a "reinstitutionalization of literary studies" (Sosnoski, 28) that will increase the institutional power of the humanities visa-vis the sciences (28). The move to the "counter" or "post-disciplinary" would provide a basis for a literary intellectual who, freed from the constraints of essentializing approaches to knowledge and with a now visible investment in 
politics, is both more connected with the "world" and more powerful within the University.

Butler's invocation of the post-disciplinary, while only a scant few paragraphs in the introduction to Gender Troubles (compared to full articles by Lentricchia and Sosnoski), repeats several key claims made by them for the post-disciplinary. Butler, centrally concerned with the question of representing gender, finds a disturbing narrative of domestication at play in the representation of women in feminist theory:

the development of a language that fully or adequately represents women has seemed necessary to foster the political visibility of women. This has seemed obviously important. (Butler, 1)

But the full and adequate representation of women required that "the qualifications for being a subject must first be met before representation can be extended" (Butler, 2). Representation in this instance shares many characteristics with submission, as the assumption of the represented subject position requires aligning oneself with pre-existing definitions of subjectivity, even though many of those definitions are anathema to feminism. In order to resist this kind of submission, but without completely abandoning the power associated with representation, Butler calls for us to "participate in whatever network of marginal zones spawned from other disciplinary centers and which, together, constitute a multiple displacement of those authorities" (Butler, xiii). From such positions one can receive some recognition as well as challenge the disciplinary structure that underwrites the restrictive definition of the subject. Butler then argues that such representations of "the complexity of gender requires an interdisciplinary and post-disciplinary set of discourses in order to resist the domestication of gender studies and or women studies within the academy" (Butler, xiii). The "post-disciplinary" would resist the essentialization of the "subject," both in the sense of the topic of research and the subject position of the researcher. As in Lentricchia and Sosnoski it would also empower the researcher and enable her to "radicalize the notion of feminist critique" (Butler, xiii).

Absent from all three calls for the post-disciplinary, however, is a consideration of the history of the disciplines. The failure to recognize the history of the disciplines acts to reinforce the idealized status of disciplinary knowledge; the disciplines seems literally outside historical and material constraints. Such an oversight is not surprising in Butler's brief rhetorical statement, but odd in Lentricchia's essay given its lengthy meditation on history and astonishing in Sosnoski's essay, whose title, "Literary Study in a Post-Modern Era: Rereading its History" would seem to announce that he will in fact give us some history of literary studies. We do receive in Sosnoski a brief "history" of "The Concept of a Discipline," the title of the first section of his paper, which goes all the way back to 1972 and Stephen Toulmin's ruminations on the difference between a discipline and a profession. $\underline{5}$ What is lost in this historical blindness is the inextricable link between Universities and the disciplinary structure. In The Conflict of the Faculties (1798) Kant presents the idea of the University as the idea of the disciplinary division of labor: 
Whoever it was that first hit on the notion of a university and proposed that a public institution of this kind be established, it was not a bad idea to handle the entire content of learning . . . by mass production, so to speak - by a division of labor, so that for every branch of the sciences there would be a public teacher or professor. (Kant, 23)

While Kant presents the idea of the disciplines as a "happy idea" the political motivations behind his argument are thinly veiled. As Derrida puts it: "Kant is well aware that he is in the process of justifying, in terms of reason, what was a de facto organization determined by the government of his day" ("Mochlos," 5). So Kant, one of the founders of the enlightenment, is in fact motivated to present knowledge as ideal because of the political realities of the late 18th century and seems far more aware of the politically contingent status of knowledge than our three authors. The disciplinary division he argued for was, following the debate over the founding of the University of Berlin, carried over as a key component of the German Education model that would have a huge influence on higher education in Germany and the United States. The founding of the idea of the University was, therefore, intricately bound up with the specific structure of the disciplines. The disciplinary structure was itself intricately bound up in the political expediencies of Prussian politics in the late 18th and early 19th century. It is not surprising that Lentricchia, Sosnoski, and Butler are suspicious of the disciplines given this political heritage; it is, however, a mistake to read the political liabilities of the disciplines as separate from those of the University.

By overlooking the foundational importance of the idea of disciplines, Lentricchia, Sosnoski, and Butler suspend the history of the University they would change. For example, in America throughout the 1800s, the German Education model made inroads, lost ground, had successes here and setbacks there, but generally came to be the dominant model of education by the early 1900s. Introducing along with the disciplines the related concepts of scholarship and publication, the development of resources such as libraries and laboratories, and the now ubiquitous idea of the lecture, the German model replaced a College centered system of higher education in which,

[if] a college had a building, it had no students. If it had students, frequently it had no building. If it had either, then perhaps it had no money, perhaps no professors; if professors, then no president, if a president, then no professors. (Rudolph, 47)

The adoption of the University model made a major contribution to stabilizing these elements. The disciplinary model, with its emphasis on research and original scholarship, required teaching space, library space, research facilities and stable administrative structures. What the German model slowly replaced was an essentially medieval system in which all students took the same courses, predominated by Greek, Latin, and religious studies, were taught as much by tutors as by professors, and spent most of their class time in recitation and drills. In 1872 all Harvard students, for example, took the same four years of prescribed courses, no electives, no specialization. However, with the introduction of the German "disciplinary" 
model and a name change from Harvard College to Harvard University, "by 1897 the prescribed course of study at Harvard had been reduced to a year of freshman rhetoric" (Rudolph, 294). The elective system allowed students to freely pursue studies in a University now structured by the disciplines and with a faculty that increased in the course of 30 years from 20 members under the old college system to more than 80 in 1897 not counting numerous lab and research assistants (Carnochan, 12).

The historical misreading that sees the question of the disciplines as distinct from the question of the University allows Lentricchia, Sosnoski, and Butler to imagine change in the disciplines, even the elimination of disciplines, as taking place against the otherwise stable institutional structure of the University. This separation allows them to deploy the prefix "post" to signify a teleological movement in which the University as a whole is improved through upsetting the disciplines. At its most basic level, the post is used as a negation, a "displacement" (Butler) or "replacement" (Sosnoski), a doing away with something, in this case the disciplines, that we usually do not like, so that we can replace it with something, in the best tradition of ad-speak, "New and Improved." Deployed as a negation, the post works as a "radical break," of one period giving way to another markedly different period that fills our desire for an improved future. The post marks the beginning of the new, the breaking away from, in terms of the University, the disciplinary. This breaking away from the old is implicit in the desire for a new that the post-disciplinary represents. Enunciating the post, therefore, places us in the present, looking forward to a break that will leave behind the present we are currently in (the present of disciplines). This suggests to me a kind utopic hope for the possibility of "making it [in this case the University] new."

While using post in this teleological sense, all three critics simultaneously muddy the historical waters further by invoking a much more Lyotardian $\underline{6}$ sense of the post. Although the post seems primarily a call for a better future, it is also involved with redefining the present. Sosnoski's repeated claim of being a "post-modern," Lentricchia's performance of counterdisciplinary reading and Butler's affirmation of positions on the "critical boundaries" suggests that the post-disciplinary is in part already upon us. The newness of post-disciplinarity is comprehended in this sense by a looking back, in this case back to the disciplinary. In describing a hoped-for future, a past of the disciplinary is inscribed which is already being surpassed. The post, in other words, thrusts the present into the past. We incarnate ourselves, through a bit of historical sleight of hand, as the nolonger-disciplinary. The post functions as a negation that invokes a utopian future in which we have surpassed our present problems, and as a marker for where we are. The desire for a better future is partly fulfilled in this deployment of the post, in that we can have newness, partially problematized, in that the new has magically become now, the now of the disciplines, and the now is what Lentricchia, Sosnoski, and Butler were hoping to change. The mis-recognition of the formative role of the disciplines causes all three to try to recuperate changes that are already happening while not being sure if those changes are the joyous harbingers of the post-disciplinary University. Once the impulse to essentalize knowledge is shifted from the disciplines themselves to the disciplinary 
structures of the University, the inter-disciplinary that seemed before so inviting can be more clearly recognized as a different disciplinary alignment within the same essentializing structure of which we should be wary. In this case, Lyotard's sense that we are always still in the modern and therefore dealing with many of same old problems of modernity should serve as a reminder that the post-modern, like the post-disciplinary, is as troublesome as the modern. Whereas Lyotard warns us about the continual presence of the modern in the post-modern, Lentricchia, Sosnoski, and Butler endorse and perform the "new." Their performances end up conserving a traditional historical view, however, by re-enacting the morality play of the revolution.

The lack of historical articulation seems partially recuperable, however, through arguing that the changes in the disciplines are not synchronous, that while we may be partially past the disciplines, we are not yet in the post-disciplinary, and the changes that are currently taking place are therefore not part of the program. In this way it is possible to see Butler's call for us to take up our positions within the liminal spaces between disciplines as perhaps the beginning of the post that will carry us into a being in the new. Unfortunately, such a strategy remains problematic. The post as a looking forward, as a call for a reorganization of academic disciplines, does not function quite so smoothly because, among other reasons, the historical forces which are bringing about the changes in the University are not entirely under our control. The "post" is a product - a byproduct, really - of the historical development of international forces, specifically late capitalism, over which we have little say. Any change we might desire in the organization and culture of the University cannot escape the logic articulated by Benjamin that the underside of culture is blood, torture, death, and murder. We should not forget what Kant seemed so aware of in 1798, that the structure of the disciplines and therefore the University, is in large part an outgrowth of the political situation in which the University exists. Insofar as we find the disciplines a suspicious idea because they came about under the direct authority of a Prussian king, we should be wary of just what power is at work, if any, undermining the disciplines today.

The assumed stability of the University that allows for the teleological deployment of the prefix post, as we have seen, completely ignores the greater disciplinary structures of the University. Having separated the question of the disciplines from the question of the University, the three critics are free to ignore all other aspects of the University, including the administrative and physical "posts" that delimit the University as a unique space. Consider the faculty posts, the appointments and chairs that are occupied at various times by various people and that mark the organization within the University as various gates mark the boundaries of the University. Derrida's discussion of Cornell, for example, in the "University in the Eyes of its Pupils" is framed by his being given a new post there "as an Andrew Dickson White Professor-at-Large" (Derrida, 5). Although he had lectured at Cornell a number of times, the post is literally a new position within and relative to the University:

In this case the title with which your University has honored me at once brings me closer to you and adds to the anguish of a 
cornered animal. Was this inaugural address a well chosen moment to ask whether the University has a reason for being? (Derrida, 5)

Derrida's nervousness at being a cornered animal is that of the animal being domesticated (both the fear of capture and of looking forward to the perhaps inevitable slaughter that accompanies domestication). His nervousness derives from his new post, which despite being at-large, is an identity very much within the University. Just as Butler has argued it should, his representation within and by the University makes him nervous for his being. His questioning of the being of the University is an awkward issue at such an address because it questions both the University and his position as constituted by the institution. This tension also raises the question of whether or not one can ask the question of the being of the University from a post, even if it is, as in this case, an outpost, of the University. The attempted resistance to essentialist subjectivity which Butler and Sosnoski call for in the post-disciplinary seems to overlook the construction of being in the representations of those posts which, while they may be disassociated from all the disciplines, i.e. at-large, still contain all of the problems of representation.

Further, the attempt to stabilize the University as the scene for disciplinary change necessarily overlooks the rather complicated series of outposts, gates, and gatekeeping that mark the physical space of the University because idealized knowledge has no physical bounds. One remarks at this juncture that it is a tradition at Indiana University and at many other schools for classes, i.e., the class of 67, to leave tributes to the University, among which gates figure prominently. In this way, classes leave behind a tribute that marks both the integrity of the University as a delimitable space, and its permeability, witnessed both by the gates and by the fact that the class has indeed left. People move in and out of the University, carrying on a correspondence between the University and the "outside" literally through the post(s). 7 The difference which the gates mark between the University and the not-University would at first seem to suggest the clear demarcation between the new and the old, the University and the not-University. The gates serve to differentiate the physical structure of the University which, if one is to think the University, one has "to think at one and the same time of the entire 'Cornellian' landscape - the campus on the heights, the bridges, and if necessary the barriers above the abyss" (Derrida, 17). The calls for a post-disciplinary University did not take the structure, the stuff of the University and its surroundings 8 into account at all. They left out a consideration of the space of the University entirely.

The correspondence the University carries on through its posts and gates emphasizes not the integrity of the University but its permeability. In Butler's call to occupy "marginal" zones between the disciplines, she overlooks the very real degree to which the University in its entirety can be seen as a kind of marginal zone. Derrida's pointing to the "bridges" of Cornell emphasizes the site of entrance and egress to the main campus, those liminal spaces which make it difficult to say just where the University begins and ends. Further, the advent of the Internet and other communication technologies further blurs the boundaries of the University 
as professors and students begin to work together across thousands of miles and almost completely outside the purview of University oversight. The valorizing of marginal spaces becomes somewhat suspect in terms of both its failure to challenge the integrity of the physical space of the University so important to its being and, simultaneously and quite paradoxically, in its failure to deal with the nature of the University as in some ways a definitively marginal space. $\underline{9}$

Moreover, the call for a post-disciplinary University overlooks the traditional role of "gatekeeper" played by University professors organized along disciplinary lines. The very physical permeability of the University discussed above has been made possible to a large extent by reliance on careful monitoring of those who would pass through the gates. To return to Kant, it is the responsibility of "faculties," organized by departments with each having a "Dean,"

to admit to the university students seeking entrance from lower schools and, having conducted examinations, by its own authority to grant or confer the universally recognized status of "doctor." (Kant, 23)

In the role of gatekeepers, administrators now function to admit students on the undergraduate level. But at the graduate level, it is largely still professors who admit students, and at all levels it is departments that confer degrees and individual faculty members within those departments who do the evaluating. Therefore, the physical space demarcated by gates, the departments and professors functioning as gatekeepers to patrol that space, and the whole associated administrative apparatus combine to form the disciplinary milieu that is the University. The attempt to dissociate the disciplines from the University, were it to be seriously attempted, would undo the space of the University completely.

The systematic idealization of knowledge in the disciplines systematically ignores importance of disciplinary structures to the University overall. This leads to an overly simplistic notion of the post-disciplinary that obscures the complicity of the University with capitalism, promotes a teleological notion of history, a naive sense of the revolutionary new, and essentializes the University as a static structure to which all instabilities and marginalities are threatening. Most disturbingly perhaps, and here I return to Weber with whom I opened this essay, there is clearly a re-evaluation of "the idea and ideal of knowledge" (Weber, ix) taking place in Universities throughout the US. The nearly ahistorical call for the post-disciplinary, by obscuring the interrelationship between the disciplines, politics, structures, space, and administration of the University, makes it difficult to evaluate what the political and intellectual stakes of the ongoing changes are. While it is unlikely that we will be able to figure out what exactly is going on, the failure to recognize the importance of the disciplinary structure in its broadest connotations renders it impossible to evaluate what the ongoing developments in our Universities might mean. 


\section{Works Cited}

Benjamin, Walter. "The Work of Art in the Age of Mechanical Reproduction." Illuminations. New York: Schocken Books, 1968.

Bennington, Geoffrey. "Deconstruction and the Philosophers (The Very Idea," Oxford Literary Review, No. 10.

Butler, Judith. Gender Trouble. New York: Routledge Press, 1990.

Carnochan, W. B. The Battleground of the Curriculum. Stanford: Stanford University Press, 1993.

Derrida, Jacques. The Post Card. Chicago: University of Chicago Press, 1987.

Derrida, Jacques. "The Principle of Reason: The University in the Eyes of Its Pupils," Diacritics, Fall 1983.

Derrida, Jacques. "Mochlos," Logomachia: The Conflict of the Faculties. Lincoln: University of Nebraska Press, 1992.

Jameson, Fredric. Postmodernism or the Cultural Logic of Late Capitalism. Durham: Duke University Press, 1991.

Kant, Immanuel. The Conflict of the Faculties. New York: Abaris Books, 1979.

Lentricchia, Frank. "Reading History with Kenneth Burke," Representing Kenneth Burke. Baltimore: John Hopkins University Press, 1982.

Lyotard, J. F. The Postmodern Condition. Minneapolis: University of Mennesota Press, 1984.

Rudolph, Frederick. The American College and University. New York: Alfred Knopf, 1962.

Sosnoski, James. "Literary Studies in a Post-Modern Era: Rereading Its History," Works and Days, vol 5, No. 1, 1987.

Thwing, Charles. The American and German University. New York: The MacMillan Company, 1928.

Weber, Samuel. Institution and Interpretation. Minneapolis: University of Minnesota Press, 1987.

1 Weber identifies the idea of disciplinary autonomy (disciplines are selfcontained, self-defining, and self-perpetuating entities) as being the central issue in debates questioning the disciplinary logic of the University (Weber IX-XI).

2LLentricchia's labeling of Burke as an anti-disciplinary critic is somewhat disingenuous. Burke, as Lentricchia notes, never received a BA. much less a 
Masters or Ph.D. Burke was also never a full-time employee of a University and was in many ways reclusive. Burke was therefore never invested in the disciplines either professionally or educationally. By and large, Burke simply ignored disciplinary concerns in his work. And when he did raise questions about the disciplinary division of learning in the University, as he does in Permanence and Change, it is in the context of raising questions about the University in general as a "bureaucratic" institution. Lentricchia symptomatically mis-reads Burke on this score both in "Reading History with Kenneth Burke" and Criticism and Social Change.

$\underline{3}$ Citing Burke as universally opposed to systematic thought is, at least, a bit perverse. One of Burke's main critical developments, Dramatism, was an attempt to provide a complete system to account for man's actions in history, art, and politics (See Grammar of Motives).

4IIn Criticism and Social Change, page 2 .

$\underline{5}$ Throughout his essay Sosnoski's discussion of the disciplines shifts registers between Toulmin's abstract considerations of the concept of a discipline and the institutional manifestation of disciplines in departments. This allows him to avoid on the one hand the institutional history of the disciplines by appealing to Toulmin's universal category of the discipline and then, shifting back to the institutional setting, avoid Toulmin's idea that disciplines don't end, they just alter their configurations over time and hence can never be really "posted."

6It is in terms of looking forward and back that the post of Lyotard and his question of "When, then, is the postmodern" (80), comes into play:

The postmodern would be that which, in the modern, puts forward the unrepresentable in presentation itself . . . Postmodern would have to be understood according to the paradox of the future (post) anterior (modo) (81).

In terms of the modern, as well as the disciplines, the post is not a beyond. The post is definitively "in" the modern, albeit in the "future" and/or in the "lead." But this lead which the post holds may fall behind, may fall literally into the past as the "essay (Montaigne) is postmodern" (81). Montaigne's formative experiments with the essay established the essay as a postmodern genre over four hundred years ago. So the post is not necessarily a looking to the future. Further, while we can certainly find the post in the past, in Lyotard it does not function as a negation. In what might be called a "first past the post" system, the post can be in the present, future or past; can in fact be passed up by the past [postmodern forms - for instance the essay again - influence newer forms - say the fragment - which are newer evolutions of the "original" postmodern form and yet which are modernisms - "the fragment (Anthaeneum) is modern" (Lyotard 80)]. While various postmodern forms may move towards the future and postmodernity may be "in the lead" it can never past the modern - in the sense of either thrusting it into the "past" or as a negation.

7This is a particularly complex notion ruminated on at length in Derrida's The Post Card as the movement and meaning of the physical postcard is 
overlaps and has similarities to but is not congruently homologous to the dissemination and meaning of the text of the postcard.

8The general importance of the University "setting" is evidenced by the prohibitions found at most Universities against altering landscapes or buildings.

9I think this is particularly clear at Indiana University. I.U., which is comprised of numerous of large buildings and striking gates, has also bled over into surrounding neighborhoods taking over a group of houses here, an individual house there, so that it is literally impossible to tell with any accuracy what the boundaries of the campus might be. Add to this a parking garage in the middle of downtown, a nuclear acceleration facility a number of miles out of town, and a new telescope being constructed by I.U. and several other Universities in Arizona, and it becomes less than clear just where I.U. is. 